\title{
Cellulose acetate obtained from Schizolobium parahyba (vell.) blake wood
}

\author{
Acetato de celulose obtidlo a partir da madeira de Schizolobium parahyba (Vell.) Blake \\ Acetato de celulosa obtenido de la madera de Schizolobium parahyba (vell.) blake
}

Received: 09/18/2021 | Reviewed: 09/24/2021 | Accept: 09/29/2021| Published: 10/02/2021

Leticia Sant'Anna Allesi
ORCID: https://orcid.org/0000-0001-6364-3028
Foundation for Research Support of the State of São Paulo, Brazil
E-mail: le_alesi1@ @ hotmail.com
Joelen Osmari da Silva
ORCID: https://orcid.org/0000-0003-1697-5075
Universidade Federal de São Carlos, Brazil
E-mail: joelenosmari@ gmail.com
Franciane Andrade de Pádua
ORCID: https://orcid.org/0000-0002-3349-8648
Universidade Federal de São Carlos, Brazil
E-mail: franciane@ ufscar.br
Vagner Roberto Botaro
ORCID: https://orcid.org/0000-0002-3382-7747
Universidade Federal de São Carlos, Brazil
E-mail: vagner@ ufscar.br

\begin{abstract}
Currently, non-biodegradable polymers are produced on a large scale and cause several environmental problems, especially due to their low degradation. Cellulose acetate is a non-toxic, low-flammable and low-cost polymer, playing an important environmental role. The objective of this study was to synthesize cellulose acetate membranes from Schizolobium parahyba wood ("guapuruvu") with particles sizes of 20 and 60 mesh. The materials were submitted to acetosolv pulping, bleaching and acetylation to produce the acetates. The yields and the degree of substitution were found. The fibers were chemically characterized and the samples obtained at each processing step were analyzed by FTIR. It was possible to prepare acetates from both granulometries wood. The FTIR analysis showed changes on the samples' bands, indicating that the chemical processes were efficient. Cellulose acetate obtained from the 60 mesh material presented a higher degree of substitution $(2.74 \pm 0.12)$ when compared to the 20 mesh acetate $(2.59 \pm 0.13)$, showing that the particle size of the material influenced on the efficiency of the acetylation reaction. DMA tests have demonstrated that the 60 mesh membrane has higher flexibility and transparency when compared to the 20 mesh membrane.
\end{abstract}

Keywords: Acetosolv pulping; Cellulose acetate; DMA; Membrane; Schizolobium parahyba.

\section{Resumo}

Atualmente, polímeros não biodegradáveis são produzidos em larga escala e ocasionam diversos problemas ambientais, principalmente devido à sua baixa degradação. $\mathrm{O}$ acetato de celulose é um polímero atóxico, pouco inflamável e de baixo custo, representando uma elevada importância ambiental. O objetivo desse trabalho foi sintetizar membranas de acetato de celulose a partir da madeira de Schizolobium parahyba (guapuruvu) com granulometrias de 20 e 60 mesh. Os materiais foram submetidos à polpação acetossolve, branqueamento e acetilação para produção dos acetatos. Foram analisados os rendimentos encontrados e o grau de substituição dos acetatos. As fibras foram caracterizadas quimicamente e as amostras obtidas em cada etapa do processamento foram caracterizadas por FTIR. Foi possível a elaboração dos acetatos com a madeira de ambas granulometrias. Os espectros de FTIR evidenciaram mudanças nas bandas das amostras indicando que os processos químicos empregados foram eficientes. $\mathrm{O}$ acetato de celulose obtido a partir do material de 60 mesh apresentou grau de substituição superior $(2,74 \pm 0,12)$ quando comparado ao acetato de 20 mesh $(2,59 \pm 0,13)$, indicando que a granulometria do material influenciou na eficiência da reação de acetilação. Os ensaios de DMA demonstraram que a membrana de 60 mesh possui maior flexibilidade e transparência quando comparada à membrana de 20 mesh.

Palavras-chave: Polpação acetossolve; Acetato de celulose; DMA; Membrana; Schizolobium parahyba.

\section{Resumen}

Actualmente, los polímeros no biodegradables se producen a gran escala y causan varios problemas ambientales, principalmente debido a su baja degradación. El acetato de celulosa es un polímero no tóxico, poco inflamable y de bajo costo, que representa una alta importancia ambiental. El objetivo de este trabajo fue sintetizar membranas de acetato de celulosa a partir de madera de Schizolobium parahyba (guapuruvu) con tamaños de partícula de 20 y 60 
mesh. Los materiales se sometieron a pulpa, blanqueo y acetilación con acetosolve para producir acetatos. Se analizaron los rendimientos encontrados y el grado de sustitución de acetatos. Las fibras se caracterizaron químicamente y las muestras obtenidas en cada paso de procesamiento se caracterizaron mediante FTIR. Fue posible preparar acetatos con madera de ambos tamaños de partícula. Los espectros FTIR mostraron cambios en las bandas de la muestra, lo que indica que los procesos químicos empleados fueron eficientes. El acetato de celulosa obtenido del material de malla 60 tuvo un mayor grado de sustitución $(2,74 \pm 0,12)$ en comparación con el acetato de malla 20 $(2,59 \pm 0,13)$, lo que indica que el tamaño de partícula del material influyó en la eficiencia de la reacción de acetilación. Las pruebas DMA demostraron que la membrana de malla 60 tiene mayor flexibilidad y transparencia en comparación con la membrana de malla 20.

Palabras clave: Despulpado con acetosolve; Acetato de celulosa; DMA; Membrana; Schizolobium parahyba.

\section{Introduction}

Currently, non-biodegradable polymers are produced on a large scale and cause several environmental problems, especially because they are resistant to degradation. In addition to the significant amount of polymeric waste, there is also the inappropriate disposal of these materials, increasing their accumulation and the problem itself (Hwang, Jeon, Youn Lee, Kim and Park, 2020; Walker \& Rothman, 2020).

Biodegradable polymers for short-term applications have attracted attention from all over the world in sectors such as surgery, pharmacology, agriculture and environment (Luckachan \& Pillai, 2011). Polymeric materials from reneweable sources have been frequently studied, for instance, bioplastics produced from cellulose (Bilo et al., 2018; Biswas, Saha, Lawton, Shogren \& Willett, 2006; Candido \& Gonçalves, 2016; Cao et al., 2018; Cerqueira, Rodrigues Filho \& Meireles, 2007; Cruz et al., 2011; Fan et al., 2013; Loo, Hashim \& Leh, 2012; Rodrigues Filho et al., 2008; Zhang, Huang, Jiang, Huang \& Yang, 2013), proteins, chitin (Ramakrishnan, Sharma, Gupta \& Alashwal, 2018), among others.

Cellulose derivatives have caused great interest in the present studies (Freitas, Senna \& Botaro, 2017). Among them, cellulose acetate (CA) which is a non-toxic, low-cost, low-flammable, biodegradable polymer that has the capacity of producing transparent films, having a high commercial (Cerqueira, Rodrigues Filho, Carvalho \& Valente, 2010) and environmental importance. Its application ranges from textile threads and photographic films to pharmaceutical capsules or covering, membranes and mostly as cigarette filters (Brum et al., 2012; Senna, Menezes \& Botaro, 2013). CA can be synthesized from the most diverse sources, including residues, as sugarcane bagasse (Cerqueira et al., 2010; Shaikh, Pandare, Nair \& Varma, 2009), rice husk (Biswas et al., 2006; Fan et al., 2013; Zhang et al., 2013), sugar cane straw (Candido \& Gonçalves, 2016), bean straw (Brum et al., 2012), mango seed (Cruz et al., 2011), among others.

Schizolobium parahyba (Vell.) Blake species (Leguminosae: Caesalpinioideae), known as "guapuruvu", is native to the Brazilian Atlantic Forest, it is also tolerant to a low water and nutritional level and to a high solar radiation (Carvalho, 2005). Besides, the species has high grow rates, close to those presented by species of the Eucalyptus gender (Gomide, Fantuzzi Neto \& Regazzi, 2010; Gonçalves et al., 2014).

The growth potential makes Schizolobium parahyba a good alternative to recover degraded areas. However, the species is not cultivated for productive purposes, mainly due to the lack of knowledge of its technological characteristics. There are few studies about the Schizolobium parahyba characterization, especially about its chemical characteristics to produce materials with higher added value and which goal is to offer the optimization of the biomass use in the biorefineries context. This way, the objective of this research was to enhance this species based on its chemical characterization and by the synthesis and mechanical characterization of cellulose acetate membranes with particle sizes of 20 and 60 mesh. 


\section{Methods}

\subsection{Schizolobium parahyba wood}

The guapuruvu wood used in this study came from an experimental planting at the Federal University of São Carlos, campus Sorocaba-SP, Brazil. The trees were planted at $3.0 \mathrm{~m}$ x $1.5 \mathrm{~m}$ spacing and harvested at 38 months of age. The area is located at approximately $23^{\circ} 35^{\prime}$ 'south and $47^{\circ} 31^{\prime}$ 'west longitude, at an average altitude of 649 meters. The regions's climate reaches an average tamperature above $22{ }^{\circ} \mathrm{C}$ with a dry winter with temperatures below $18{ }^{\circ} \mathrm{C}$, characterizing itself as hot and humid tropical (Pinheiro, Tonello, Valente, Mingoti \& Santos, 2011).

\subsection{Fibers separation by granulometry}

The material, with no husk, was ground in a Willey knife mill, Marconi - MA 340, using a fixed speed of $1750 \mathrm{rpm}$. For the separation of the granulometries, after grinding, the Orbital Shaker with Intermittent Beating Marconi - MA 750 was used, using $100 \mathrm{~g}$ of biomass for five minutes. The sequence of the granulometric system was 9, 20, 35, 60 mesh sieves and the collector for thiner particles.

For the analyzes, the material retained in the 20 mesh $(0.841 \mathrm{~mm})$ and 60 mesh $(0.250 \mathrm{~mm})$ sieve was used for future steps, in order to evaluate the effect of the surface area on the pulping process and subsequently to obtain the membranes.

\subsection{Chemical characterization}

For the chemical characterization of the guapuruvu wood, it was used the material retained in the 60 mesh sieve. All analyzes were performed in triplicate.

\subsubsection{Ash content}

The ash content was determined based on ASTM D1102-13 standard. Approximately $1.0 \mathrm{~g}$ of dry material was weighed into a previously calcined porcelain crucible. The set was placed in a JUNG model 0212 muffle furnace at a temperature of $600{ }^{\circ} \mathrm{C}$ for 6 hours. The crucible was cooled to room temperature in a desiccator and then weighed.

\subsubsection{Extractives}

Extracts such as resins are soluble in hot water, while sugars are soluble in organic solvents. Thus, a sequence of three extractions was used: extraction in cyclohexane solution: ethanol (1:1), ethanol and hot water, with a total of 24 cycles for each extraction. The content of soluble extracts in organic solvents was determined according to TAPPI T204 cm-97 standard with adaptations, while the content of hot water soluble extracts was determined according to the ASTM D1110-84 standard with adaptations.

\subsubsection{Insoluble Lignin Klason}

The Klason lignina content was determined based on ASTM D1106-13 standard. Approximately $1.0 \mathrm{~g}$ of material, dry and without extractives, was weighed, placed in a beaker and $15 \mathrm{~mL}$ of sulfuric acid $(72 \%$ concentration maintained at a temperature between 10 and $15{ }^{\circ} \mathrm{C}$ ) was added. This mixture was kept in an ice bath at $2^{\circ} \mathrm{C}$ and macerated to disperse the material. After dispersion, the whole was covered with a watch glass and placed in a water bath at $20^{\circ} \mathrm{C}$ under stirring for 2 hours. In a $500 \mathrm{~mL}$ Erlenmeyer flask, $300 \mathrm{~mL}$ of water was added and the solution prepared from the beaker was diluted to $3 \%$ sulfuric acid and boiled for 4 hours at constant volume. Finally, the solution was filtered in a buchner funnel until reaching 37 $\mathrm{pH}$ close to that of water. The filter paper with the retained material was taken to an oven at $80^{\circ} \mathrm{C}$ and, after drying, were weighed. 


\subsubsection{Holocelulose}

The holocellulose content was determined based on ASTM D1104-56 standard. In a 500 ml Erlenmeyer flask, 3.0 g of dry material without extractives was added together with $120 \mathrm{ml}$ of distilled water. Then $2.5 \mathrm{~g}$ of sodium chlorite and $1.0 \mathrm{ml}$ of glacial acetic acid were added. This set was capped and placed in a water bath at $70{ }^{\circ} \mathrm{C}$ under constant agitation. After 1 hour, $2.5 \mathrm{~g}$ of sodium chlorite and $1.0 \mathrm{ml}$ of glacial acetic acid were added again. This procedure was repeated once more after 1 hour. The reaction took place for another 3 hours and the vials were placed in an ice bath for 30 minutes. The material was washed with distilled water and acetone and filtered in a buchner funnel until it reached a pH close to that of water. The filter paper with the retained material was taken to an oven at $80^{\circ} \mathrm{C}$ and, after drying, were weighed.

\subsection{5 $\alpha$-celulose}

The $\alpha$-cellulose content of the raw material was determined based on ASTM D1103-60 standard. Alpha cellulose refers to whole cellulose. Approximately $1.0 \mathrm{~g}$ of the previously prepared holocellulose was weighed. The material was macerated until homogeneous and then $10 \mathrm{~mL}$ of sodium hydroxide (concentration $17.5 \%$ ) was added. The system was left to rest for 2 minutes. Then, this sample was macerated for another 8 minutes. Again, $10 \mathrm{~mL}$ of $\mathrm{NaOH}$ were added, leaving the system to rest for another 20 minutes. Then, $40 \mathrm{~mL}$ of distilled water were added and the mixture was filtered in a buchner funnel until it reached a $\mathrm{pH}$ close to that of water. The filter paper with the retained material was taken to an oven at $80^{\circ} \mathrm{C}$ and, after drying, were weighed.

\subsection{Chemical pulping}

The acetosolv pulping process was used for the disintegration of the cellulosic fibers and for lignin extraction, since the solvents can be purified and reused; in addition the process has a lower cost when compared to the usual processes. The Acetosolv process for the guapuruvu wood pulping was based on the method proposed by Botaro (1992). Pulping was performed for both 20 and 60 mesh granulometries. It was used $25 \mathrm{~g}$ (dry weight) and a $250 \mathrm{~mL}$ solution containing $92.9 \%$ acetic acid, $0.3 \%$ hydrochloric acid and $6.8 \%$ distilled water. The set was placed in a reaction flask connected to a condenser and was kept under constant agitation at $100^{\circ} \mathrm{C}$ for 3 hours. Finally, the solution was washed with distilled water and filtered with a Büchner funnel, the material was taken to an oven at $60^{\circ} \mathrm{C}$ for $24 \mathrm{~h}$. The brown pulp yield was calculated based on the relationship between the dry brown pulp weight $(\mathrm{g})$ and the initial dry fiber weight $(\mathrm{g})$.

\subsection{Bleaching of the produced pulp}

The bleaching process was based on the method proposed by Botaro (1992). In a $500 \mathrm{ml}$ Erlenmeyer, $6 \mathrm{~g}$ of cellulose pulp, previously prepared, $240 \mathrm{ml}$ of distilled water, $2 \mathrm{ml}$ of acetic acid and $5 \mathrm{~g}$ of sodium chlorite were added. This set was covered and kept in a water bath at $70^{\circ} \mathrm{C}$ under constant agitation. After 30 minutes, $2 \mathrm{ml}$ of acetic acid and $5 \mathrm{~g}$ of sodium chlorite were added again. These same additions occurred 2 more times every 30 minutes. After the additions, the solution occurred for another 30 minutes and was kept in an ice bath to stop the reaction. The bleached pulp was washed with distilled water and filtered with a Büchner funnel, the material was taken to an oven at $60{ }^{\circ} \mathrm{C}$ for $24 \mathrm{~h}$. The bleached pulp yield was calculated based on the relationship between the dry bleached pulp weight and the initial brown pulp weight $(\mathrm{g})$.

\subsection{Sinthesis of celulose acetate}

The cellulose acetylation followed the procedures of Cerqueira et al. (2007) using the obtained bleached pulps. In a beaker, $1 \mathrm{~g}$ of the bleached pulp and $25 \mathrm{ml}$ of glacial acetic acid were added. The set was kept under agitation at room temperature for 30 minutes. Subsequently, $0.08 \mathrm{~mL}$ of sulfuric acid and $9 \mathrm{~mL}$ of glacial acetic acid were added, allowing the 
reaction to proceed for an additional 25 minutes. Finally, $32 \mathrm{ml}$ of acetic anhydride was added, maintaining the reaction for another 30 minutes. The beaker was then covered with PVC film and held for 24 hours. After that time, $100 \mathrm{ml}$ of distilled water was added to precipitate the material. The acetate was washed with distilled water, filtered with a Büchner funnel and taken to the oven at $60^{\circ} \mathrm{C}$ for $24 \mathrm{~h}$. The acetate yield was calculated based on the relationship between the cellulose acetate weight and the initial weight of the bleached pulp (g).

\subsubsection{Determination of the degree of substitution of the cellulose acetate}

The degree of substitution of the cellulose acetates was determined on the ASTM D 871-96 standard. The calculation of the degree of substitution can be found in the equations 1 and 2.

$\%$ acetyl $=\frac{\left\{\left[\left(V_{\mathrm{NaOH}} x A\right)-\left(V_{\mathrm{HCl}} x B\right)\right]-\left[\left({V^{\prime}}_{{ }_{N a O H}} x A\right)-\left(V^{\prime}{ }_{H C l} x B\right)\right]\right\}}{w} x 4,3$

Equation 1

Where: \% acetyl: percentage of acetyl groups in the sample (\%); $\mathrm{V} \mathrm{NaOH}$ : volume of the $\mathrm{NaOH}$ solution in the $\mathrm{CA}$ sample $(\mathrm{mL})$; $\mathrm{V} \mathrm{HCl}$ : volume of the $\mathrm{HCl}$ solution used for the titration of the $\mathrm{CA}(\mathrm{mL})$; V'NaOH: volume of the $\mathrm{NaOH}$ solution in the beached cellulose sample $(\mathrm{mL})$; $\mathrm{V}^{\prime} \mathrm{HCl}$ : volume of the $\mathrm{HCl}$ solution used for the titration of the bleached cellulose $(\mathrm{mL})$; A: concentration of $\mathrm{NaOH}$ in $\mathrm{mol} / \mathrm{L}$; B: concentration of $\mathrm{HCl}$ in mol/L; W: sample weight $(\mathrm{g})$.

$D S=\frac{3,86(\% \text { acetyl })}{102,4-(\% \text { acetyl })}$

Equation 2

Where DS = degree of substitution.

\subsection{Preparation of the cellulose acetate membrane}

In an Erlenmeyer, $0.75 \mathrm{~g}$ of cellulose acetate and $25 \mathrm{ml}$ of chloroform were added. The set was kept under agitation for 4 hours, until the total dissolution of the material. Then, the resulting liquid was transferred to a $9 \mathrm{~cm}$ diameter Petri dish, free of impurities. The plate was covered with a watch glass and kept at rest so that solvent evaporation (casting) would occur without bubbles (Shaikh et al., 2009).

\subsection{Fourier-transform infrared spectroscopy analysis (FTIR)}

To identify the composition and the chemical structure of the samples, it was performed the FTIR analysis of the raw guapuruvu, the brown and beached pulps and the cellulose acetates produced from 20 and 60 mesh particle sizes, in the wave number range between 600 and $4000 \mathrm{~cm}^{-1}$. For this, a Perkin Elmer Spectrum 400 FT-IR spectrophotometer was used in the biomaterials laboratory of PUC-SP, Sorocaba campus.

\subsection{Dynamic mechanical thermal analysis (DMA)}

To check the mechanical stability, deformation and resistance of the membranes, the DMA equipment (model Q 800, TA Instruments) was used, with the tension clamp for film. The specimens had dimensions of approximately: $10 \mathrm{~mm} \times 7 \mathrm{~mm} \times$ $0.5 \mathrm{~mm}$ (length / width / thickness).

For the stress analysis, a pre-load force of $5.0 \mathrm{~N}$ was applied, an isothermal temperature of $37.5^{\circ} \mathrm{C}$, a force ramp rate of $3 \mathrm{~N} / \mathrm{min}$ and a maximum applied force of $18 \mathrm{~N}$. 
From the stress / strain analysis, it was also possible to calculate the Young's modulus. In polymers, it can be obtained from the stress ratio for the region's deformation below $0.2 \%$, and the higher the Young's modulus obtained, the greater the polymer's stiffness and, consequently, the greater its resistance to elastic deformation (Canevarolo , 2013). Young's modulus is given by equation 3 .

$$
E=\frac{\Delta \sigma}{\Delta \varepsilon}
$$

For the single temperature / frequency ramp analysis, a pre-load force of $0.15 \mathrm{~N}$, an amplitude of $4 \mu \mathrm{m}$ and a heating rate of $3{ }^{\circ} \mathrm{C} / \mathrm{min}$ was applied, analyzing between 25 and $220^{\circ} \mathrm{C}$.

\section{Results and discussion}

\subsection{Particle size distribution}

From the separation, most of the material, approximately 58\%, was retained in the 20 mesh $(0.841 \mathrm{~mm})$ sieve; followed by the 35 mesh $(0.5 \mathrm{~mm})$ sieve, where approximately $38 \%$ of the material was retained. The 9 mesh $(2.0 \mathrm{~mm})$ and 60 mesh $(0.250 \mathrm{~mm})$ sieves had the lowest retained mass, with approximately $0.03 \%$ and $2.3 \%$, respectively. With this result, it was possible to verify the granulometric distribution of the sample after grinding and showed the fractions with greater retained mass.

\subsection{Chemical composition}

The results of the chemical analysis for raw guapuruvu are shown in Table 1.

Table 1. Chemical composition of Guapuruvu wood (Schizolobium parahyba).

\begin{tabular}{cc} 
Chemical Analysis & Composition (\%) \\
\hline Ash content & $1,09 \pm 0,04$ \\
Total Extractives & $10,65 \pm 0,42$ \\
Klason Lignin & $24,33 \pm 1,94$ \\
Holocellulose & $70,89 \pm 2,17$ \\
a-cellulose & $40,65 \pm 2,12$ \\
\hline
\end{tabular}

Source: Authors.

The ash content for guapuruvu $(1.09 \% \pm 0.04 \%)$ was close to the study of Silva (2018), who found an average of $1.19 \% \pm 0.06 \%$ studying the same material. Such value was considered high when compared to the work of Narita, Nakashima, Róz, Pires and Yamaji (2018) who found a value of $0.68 \%$ for the same species and with the work of Melo, Menezzi, Souza and Stangerlin (2013) who found a value of $0.6 \%$ for Schizolobium parahyba var amazonicum. The value found in this work was higher when compared to other species used for cellulose production, like those found by Protássio $e t$ al. (2011), such as Eucalyptus urophylla (0.25\%) and Pinus sp. (0.39\%).

Silva (2018) obtained a total extractives content of $10.37 \% \pm 0.86 \%$ close to the $10.65 \% \pm 0.42 \%$ of the present study. Vidaurre, Carneiro, Vital, Santos and Valle (2012), studying Schizolobium parahyba var amazonicum wood, obtained a total extractive content of $4.4 \%$, lower than the values obtained in this work, this can be explained by the use of ethanol / toluene 
and hot water and not having used cyclohexane / ethanol which was the solvent with the highest percentage of removal of extracts from the material $(7.95 \% \pm 0.58)$.

Extractives reduce the action of the reagents and the process yield, affecting the final product due to a greater difficulty for chemical solvents to penetrate the biomass (Alves, Gomide, Colodette \& Silva, 2011; Trugilho et al., 2015).

The lignin results obtained by Silva (2018) were $21.13 \% \pm 2.74 \%$; a value close to the $24.33 \% \pm 1.94$ found in this study. The value of lignin was also close when compared to commercial wood species for the production of cellulose (pine and eucalyptus), Vivian et al. (2015) found values of $26.18 \%$ for Pinus taeda and $25.15 \%$ for Pinus sylvestris. Severo, Calonego and Sansígolo (2006) found a value of $23.31 \%$ for Eucalyptus citriodora. The main objective of the cellulose manufacture is to break the lignin chains to release cellulosic fibers. Low-lignin and extractives woods provide a purer pulp with higher yields (Gomide et al., 2010; Trugilho et al., 2015).

The holocellulose content obtained for guapuruvu $(70.89 \% \pm 2.17)$ was close to that obtained by Silva (2018) who found an average of $70.24 \% \pm 2.42 \%$. It was also close to the work of Trugilho et al. (2015) studying 15 clones of Eucalyptus urophylla $\mathrm{x}$ Eucalyptus grandis whose values ranged from $70.98 \%$ to $82.04 \%$. As the holocellulose content refers to the total carbohydrates present in the material (polioses and cellulose), it is interesting that this value is high to provide greater cellulose pulp yields.

The $\alpha$-cellulose content $(40.65 \% \pm 2.12)$ was close to that obtained by Silva (2018) of $38.54 \%$ and lower than that obtained by Santos, Mello Júnior, Caraschi, Ventorim and Pereira (2016) for hybrids of Eucalyptus urophylla x Eucalyptus grandis (51.95\%) and Trugilho et al. (2015) studying the same species (51.60\% to $60.76 \%$ ). The content of $\alpha$-cellulose refers to cellulose that is intact, being important for the production of cellulose pulp.

\subsection{Yields of brown, bleached pulps and cellulose acetates}

Table 2 demonstrated the average yields obtained in the pulping, bleaching and acetylation tests for the 20 and 60 mesh materials.

Table 2. Yields obtained from pulping, bleaching and acetylation processes from 20 and 60 mesh fibers.

\begin{tabular}{cccc} 
Granulometry & Brown Pulp (\%) & Bleached Pulp (\%) & Cellulose Acetate (\%) \\
\hline 20 mesh & $61.08 \pm 1.27$ & $82.61 \pm 5.04$ & $43.07 \pm 3.20$ \\
60 mesh & $56.32 \pm 2.03$ & $78.20 \pm 4.79$ & $47.26 \pm 6.57$ \\
\hline
\end{tabular}

Source: Authors.

Joaquim, Tonoli, Santos and Savastano Junior (2009) studying the organosolv process for the production of sisal pulps obtained yields in brown pulp ranging between 56.4\% and 60.9\%. Thus, the yields are consistent with those of this study. In the work of Gomide et al. (2010), the authors used kraft pulping in clones of Eucalyptus sp. with commercial age and an average yield of brown pulp of 49.5\%. Carvalho, Silva and Colodette (2014) also studying clones of Eucalyptus sp. with kraft pulping, obtained an average yield in brown pulp of $52.7 \%$ for clones of 7 years, $54.27 \%$ for clones without defined age and 51.6\% for clones of 3 years. The bleaching yields were lower than the study of Mokfienski et al. (2008) using oxygen and peroxide (96.8\%) with clones of Eucalyptus sp., without defined age.

The average values of yield in brown pulp $(61.08 \pm 1.27)$ and bleached pulp $(82.61 \pm 5.04)$ for the material with granulometry of 20 mesh were higher than for the brown pulp obtained with 60 mesh $(56.32 \pm 2.03)$ and bleached $(78.20 \pm$ 4.79), which indicates that the smaller the particle size, the lower the yield and the efficiency of the processes. This was due to the 60 mesh material having a larger contact surface, facilitating the exposure to the temperature and the solvent attack. So, 
there was not only an attack on lignin and polioses, but also on cellulose during the acetosolv pulping and bleaching process, reducing the process yield.

The cellulose acetates produced from the bleached 60 mesh pulp showed greater mass gain $(47.26 \pm 6.57)$ when compared to the bleached 20 mesh pulp $(43.07 \pm 3.20)$. In other words, the smaller particle size provided better acetylation. According to Brum et al. (2012) and Peredo et al. (2015), the higher degree of substitution of hydroxyl groups by acetyl groups, increases not only the yield but also the solubility of acetate in solvents such as chloroform, providing a greater transparency in the obtained membrane.

According to Brum et al. (2012), it is expected that the material from the acetylation reaction will have greater mass than the initial material, due to the replacement of hydroxyl groups by acetyl, which have greater volume and mass. This result was confirmed since the 60 mesh material showed higher acetate yield and, consequently, a higher degree of substitution. It can be seen from Table 2 that the granulometry of the material affected the yield results in brown pulp, bleached pulp and cellulose acetates. Figure 1 illustrates the changes in the appearance of the materials with particle size of 20 and 60 mesh during the treatment sequence from grinding to the final product.

Figure 1. Raw guapuruvu fibers, brown pulps, bleached pulps, celulose acetates and membranes produced from the 20 mesh material (A, B, C, D e E) and 60 mesh (F, G, H, I, J), respectively.

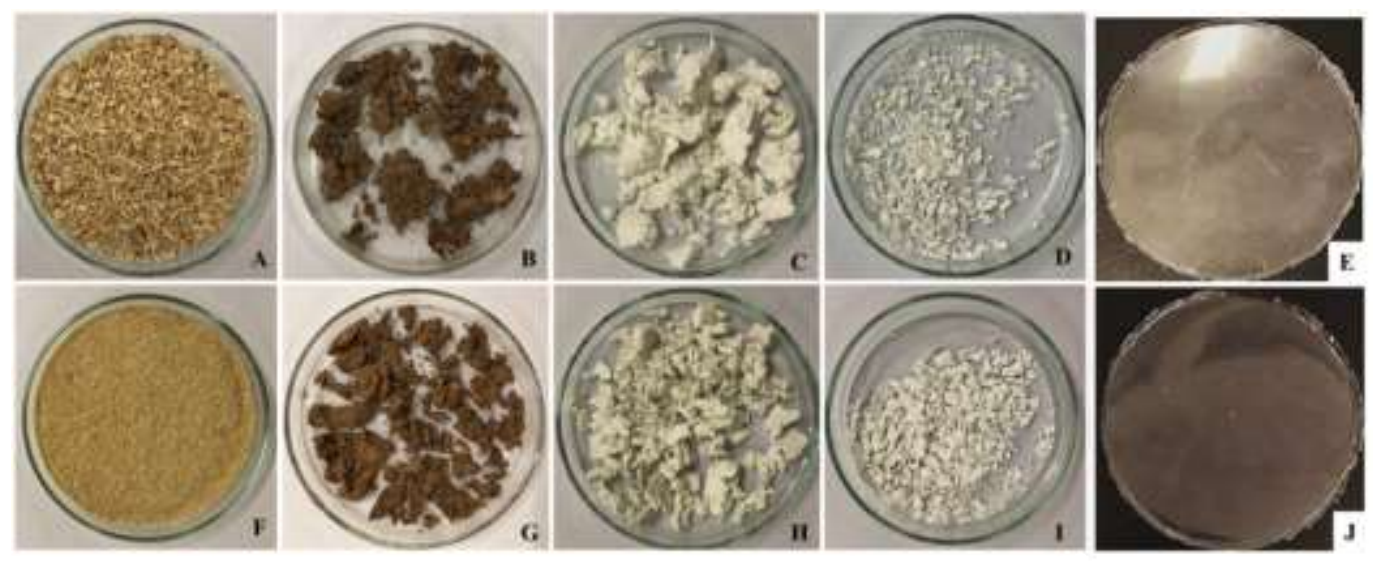

Source: Authors.

Figure 1 shows the change in the surface and coloration from untreated fibers. The pulps from the acetosolv pulping process (B and G) are brown in color due to the presence of residual lignin. Pulps $\mathrm{C}$ and $\mathrm{H}$, on the other hand, have a white color, suggesting the removal of excess lignin that existed before the bleaching process. The acetates produced (D and I) also have a white color and, unlike cellulose, they showed good dissolution in solvents such as acetone, chloroform and tetrahydrofuran (THF), the produced membranes (E and J) have high transparency.

\subsection{Degree of substitution of the cellulose acetates}

The acetylation reaction used can lead to the formation of cellulose monoacetates, diacetates or triacetates, in which one, two or three hydroxyl groups are replaced by acetyl groups, respectively. Thus, the analysis of the degree of substitution is important to verify the solubility of the material produced and enable a better application (Cerqueira et al., 2010).

The acetylation reaction influences the solubility of the material since the acetyl groups are more hydrophobic than the hydroxyl groups present in cellulose. The replacement of hydroxyl groups by acetyl groups makes the material more soluble in nonpolar organic solvents (Peredo et al., 2015). 
In the present study, the acetates obtained were classified as triacetates. Thus, the solvent chosen for dissolution was chloroform, as triacetates are soluble in chlorinated solvents (Biswas et al., 2006; Rodrigues Filho et al., 2008). The cellulose acetate obtained from the 60 mesh material showed a higher degree of substitution $(2.74 \pm 0.12)$ when compared to the 20 mesh acetate $(2.59 \pm 0.13)$, indicating that the particle size of the material influenced in the obtained acetylation efficiency.

According to Peredo et al. (2015), commercial cellulose acetate has a degree of substitution of 2.54, which is lower than the acetates produced with granulometry of 20 and 60 mesh with guapuruvu in the present work. Rodrigues Filho et al. (2008) studying the influence of time on acetylation of recycled newspaper, obtained a substitution degree of 1.98 for the 48hour reaction and 2.79 for the 24 -hour reaction, a value close to the 60 mesh acetate of the present study with 24 hours of reaction. The same authors mention that the residual lignin present in the pulp influences the acetylation efficiency, the lower the lignin content, the greater the degree of substitution.

Shaikh et al. (2009) studying the acetylation of sugarcane bagasse found a degree of substitution ranging from 2.8 to 2.9 after 6 hours of reaction. In this study, the authors state that the reaction stabilizes after 6 hours of acetylation. Variations of this type may occur because it's another type of raw material.

In the work of Sun, Fang, Tomkinson and Jones (1999), the authors verified the degree of substitution of acetylation of wheat straw polioses. The results were quite low, varying from 0.74 to 1.49 , showing the importance of the pulping process to obtain a pulp with a high cellulose content.

An even lower degree of substitution (0.14) was found in the work of Wang and $\mathrm{Li}$ (2018), studying the acetylation of bleached eucalyptus pulp. The authors explain that this value was probably due to the lack of a catalyst in the acetylation process, where only acetic acid and acetic anhydride were used.

\subsection{Fourier-transform infrared spectroscopy analysis (FTIR)}

Figures 2 and 3 illustrate the FTIR spectra obtained for guapuruvu, brown pulp, bleached pulp and cellulose acetate obtained with the fibers with 20 and 60 mesh particle size, respectively. Figure 4 shows the FTIR spectra for the membranes obtained with the cellulose acetates. 
Figure 2. FTIR of guapuruvu fiber, brown pulp, bleached pulp and cellulose acetate obtained with the 20 mesh particle size.

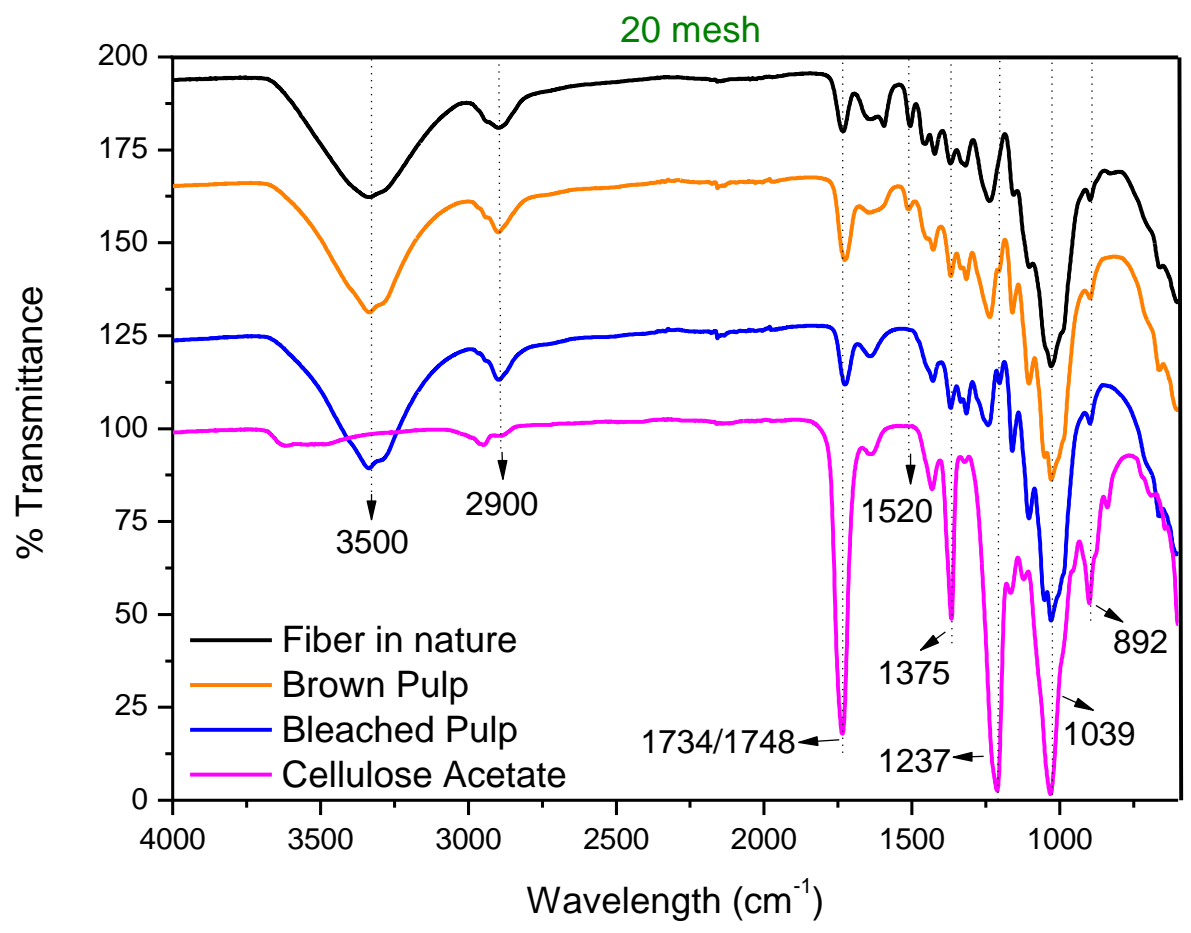

Source: Authors.

Figura 3. FTIR of guapuruvu fiber, brown pulp, bleached pulp and cellulose acetate obtained with the 60 mesh particle size.

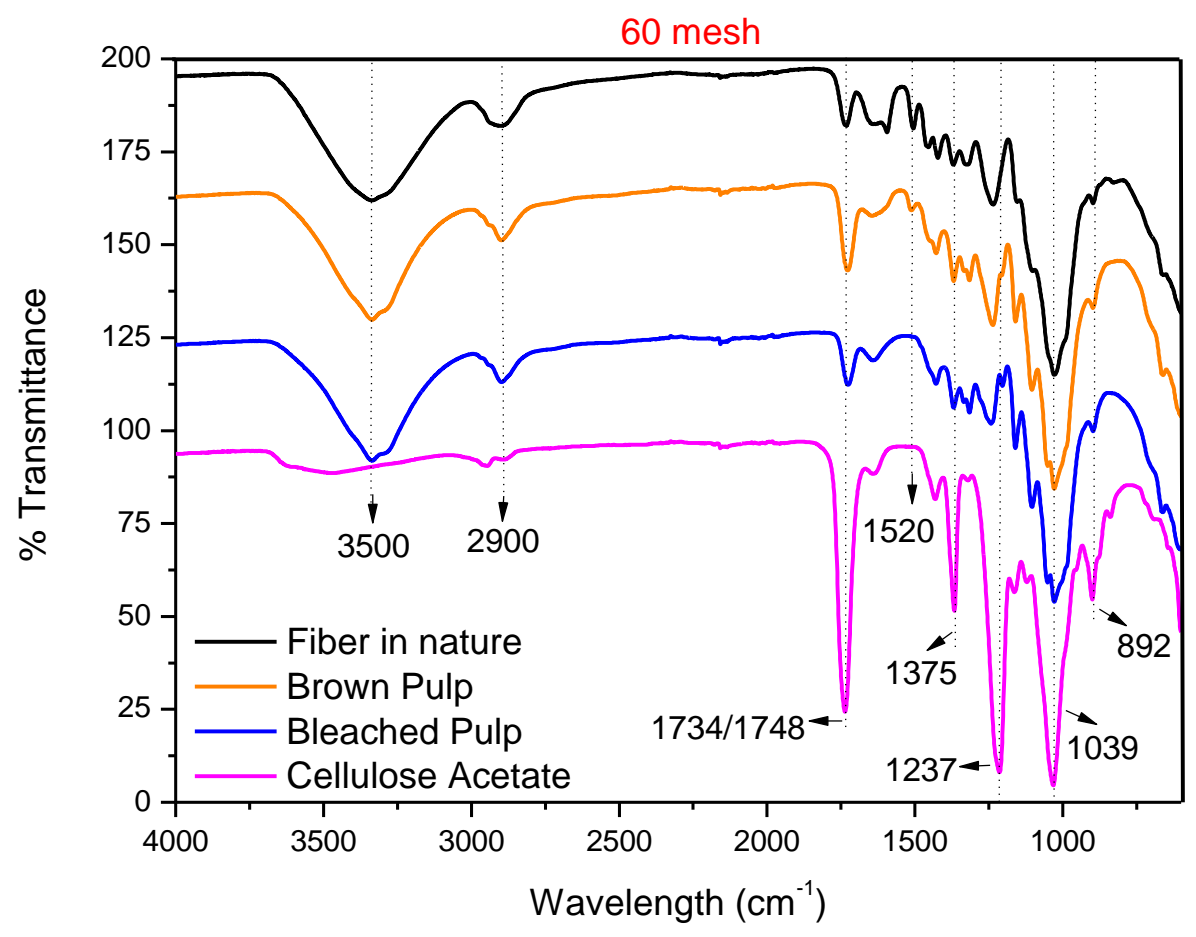

Source: Authors 
It is noted that the profile of the materials spectra for all processes are very similar for both particle sizes studied.

The $1039 \mathrm{~cm}^{-1}$ band is attributed to the polysaccharide stretch: $\mathrm{C}-\mathrm{O}$ bonds, $\mathrm{C}-\mathrm{O}-\mathrm{C}$ stretch and flexion of the $\mathrm{C}-\mathrm{OH}$ bond. This band persists from the raw materials to the produced membranes. This band is related to cellulose and was expected since it is the main polysaccharide found in all samples (Ren, Sun, Liu, Cao \& Luo, 2007; Sun et al., 1999).

Several authors mention that the $892 \mathrm{~cm}^{-1}$ band is due to $\beta$-glycosidic bonds between cellobiose units. A small increase of this band is noticed in the acetate spectra. The same behavior was found in other studies that studied the behavior of the acetylation in wheat straw (Ren et al., 2007; Sun et al., 1999) and rice straw (Fan et al., 2013). In the literature, some authors have studied the acetylation of pulps from different biomasses and reported what happens to some bands after the bleached pulp undergoes the acetylation process. The main variation concerns the decrease in the band of hydroxyl groups $\left(3300 \mathrm{~cm}^{-1}\right)$ due to their replacement by acetyl groups (Fan et al., 2013; Loo et al., 2012; Peredo et al., 2015; Rodrigues Filho et al., 2008; Zhang et al., 2013). The complete disappearance of this band is not observed even in triacetates (Shaikh et al., 2009).

There is also a decrease in the band referring to the symmetrical stretching of $\mathrm{CH}_{2}\left(2900 \mathrm{~cm}^{-1}\right)$ and the appearance of two more bands: $1237 \mathrm{~cm}^{-1}$ (stretching of $\left.\mathrm{C}-\mathrm{O}\right)$ and $1375 \mathrm{~cm}^{-1}(\mathrm{C}-\mathrm{H}$ connection in groups $-\mathrm{O}(\mathrm{C}=\mathrm{O})-\mathrm{CH} 3$. The same behavior was observed in studies with the acetylation in cotton (Peredo et al., 2015), bean straw (Brum et al., 2012), rice straw (Fan et al., 2013; Zhang et al., 2013), Eucalyptus globulus (Peredo et al., 2015) and pine (Popescu, Larsson, Olaru \& Vasile, 2012). According to the literature, changes in these bands are characteristic of acetylation, demonstrating that it occurred satisfactorily (Cerqueira et al., 2007; Peredo et al., 2015; Ren et al., 2007; Shaikh et al., 2009; Sun et al., 1999). The mentioned bands are illustrated in Figures 2 and 3.

Figure 4. FTIR of the cellulose acetate membranes obtained with guapuruvu of 20 and 60 mesh.

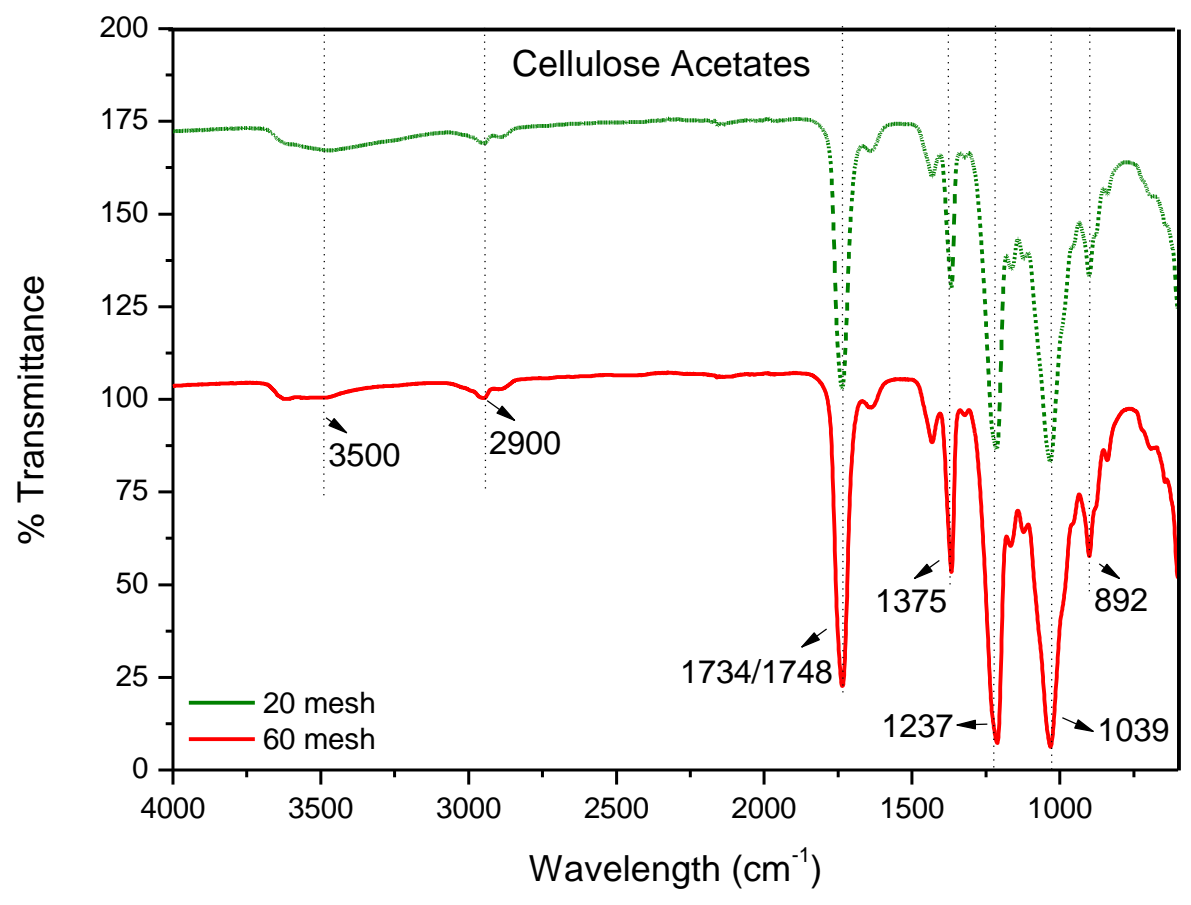

Source: Authors. 
The absence of the 1760-1840 $\mathrm{cm}^{-1}$ and $1700 \mathrm{~cm}^{-1}$ bands indicates that the acetic anhydride and the acetic acid are not present in the acetates. In this way, it can be concluded that the acetylation reaction occurred successfully and that the reagents were eliminated during the washing of the acetates (Popescu et al., 2012; Shaikh et al., 2009).

According to Fan et al. (2013), the $1734 \mathrm{~cm}^{-1}$ transmittance peak is characteristic of the aliphatic ester groups present in lignin, which persisted from the raw material to the bleached pulp. However, in the acetate spectrum, this peak increases considerably. Some authors mention that after acetylation, there is actually an increase in the band associated with the carboxyl groups $\mathrm{C}=\mathrm{O}\left(1748 \mathrm{~cm}^{-1}\right)$ (Brum et al., 2012; Loo et al., 2012; Peredo et al., 2015; Popescu et al., 2012; Rodrigues Filho et al., 2008). Thus, there may have been an overlap with the bands $1734 \mathrm{~cm}^{-1}$ and $1748 \mathrm{~cm}^{-1}$, increasing its intensity. The $1520 \mathrm{~cm}^{-1}$ band appears in the spectra of the raw material and the brown pulp, disappearing in the bleached pulp, acetate and membranes. According to Fan et al. (2013), this band refers to the $\mathrm{C}=\mathrm{C}$ vibrations of the aromatic lignin skeleton, showing that the pulping process extracted a large part of this constituent.

Figure 4 shows that the bands referring to the cellulose acetate are more intense on 60 mesh membranes than on 20 mesh membranes. This result coincides with the higher degree of substitution obtained for 60 mesh membranes, indicating that the particle size of the material is directly related to the efficiency of the acetylation process.

In Figure 4, the large band located between $3000-3700 \mathrm{~cm}^{-1}$ refers to the $\mathrm{OH}$ group of the molecularly adsorbed water. This band overlaps with the peak corresponding to the $\mathrm{OH}$ of the non-acetylated groups of the cellulose acetate that is present in the $3500 \mathrm{~cm}^{-1}$ band (Mendes, Faria, Carvalho, Gonçalves \& Pinho, 2018).

\subsection{Dynamic mechanical thermal analysis (DMA)}

The membranes of both sizes did not break during the stress / strain analysis, reaching only the phase of elastic deformation. Although more analyzes are necessary to obtain the stress / strain in the flow, stress / strain in the rupture and tenacity, it is possible to say that the resistance to deformation of the membranes was higher than $18 \mathrm{~N}$ and that there was a difference in the percentage of the deformation.

As a result of the data obtained from the stress / strain graph, Table 3 was made, which contains the maximum stress and strain and the Young's modulus for the obtained membranes.

Table 3. Maximum stress and strain and Young's modulus of the obtained membranes.

\begin{tabular}{cccc}
\hline Membrane & $\begin{array}{c}\text { Maximum Voltage } \\
(\text { MPa ou N/mm²) }\end{array}$ & $\begin{array}{c}\text { Maximum } \\
\text { Deformation (\%) }\end{array}$ & $\begin{array}{c}\text { Young's } \\
\text { Modulus (MPa) }\end{array}$ \\
\hline 20 mesh & 9.47 & 0.69 & 1364.69 \\
60 mesh & 6.55 & 0.55 & 1173.00 \\
\hline
\end{tabular}

Source: Authors.

The Young's modulus of the 20 mesh membrane was approximately $1364.69 \mathrm{MPa}$ while the 60 mesh membrane was approximately $1173 \mathrm{MPa}$. Having in mind that the greater the Young's modulus, the greater the material's stiffness, these results indicate a greater resistance to the elastic deformation of the 20 mesh membrane, being $14.05 \%$ more resistant when compared to the 60 mesh membrane.

As previously discussed, the 60 mesh membrane is made up of smaller particles, with a larger contact surface to react with solvents during reactions. Thus, acetylation occurred more efficiently, producing an acetate with a higher degree of substitution. Due to the greater contact surface, such particles are also more likely to the degradation of polymeric chains and, 
consequently, the mechanical properties of the 60 mesh membrane were also affected, presenting less stress and maximum deformation in relation to the 20 mesh membrane.

This result can be explained by the variation in the degree of substitution of acetates. The cellulose acetate of the 60 mesh membranes showed a higher degree of substitution than the 20 mesh membranes, being 2.74 and 2.59, respectively, so, they have a smaller number of hydroxyl groups, as these were replaced by acetyl groups. In this way, they form less inter and intramolecular hydrogen bonds, favoring a greater sliding between the chains and, consequently, having greater elasticity than the 20 mesh membrane.

According to Abdel-Naby and Al-Ghamdi (2014a and 2014b) the Young's modulus of cellulose acetate is approximately $1500 \mathrm{MPa}$, a value close to those obtained for the samples in question.

The temperature variation in relation to the amount of energy stored is called the storage module, which refers to the elastic behavior of the polymer. The temperature variation in relation to the amount of energy dissipated by the material is called the loss module, being the region of viscous behavior. The delta tangent, or loss factor (Tan $\delta$ ), is the ratio between the storage module and the loss module and allows to evaluate the molecular movements of the material according to the temperature variation (Callister, 2008; Lorandi, Cioffi \& Ornaghi Junior, 2016). Figure 5 illustrates the curves of the Loss Module (E”), Storage Module (E') and Loss Factor $(\operatorname{Tan} \delta$ ) in relation to the temperature of the cellulose acetate membranes obtained from 20 and 60 guapuruvu fibers.

Figure 5. Curves of Loss Module (E”), Storage Module (E') and Loss Factor (Tan $\delta) x$ temperature of the cellulose acetate membranes obtained from 20 and 60 mesh guapuruvu fibers.

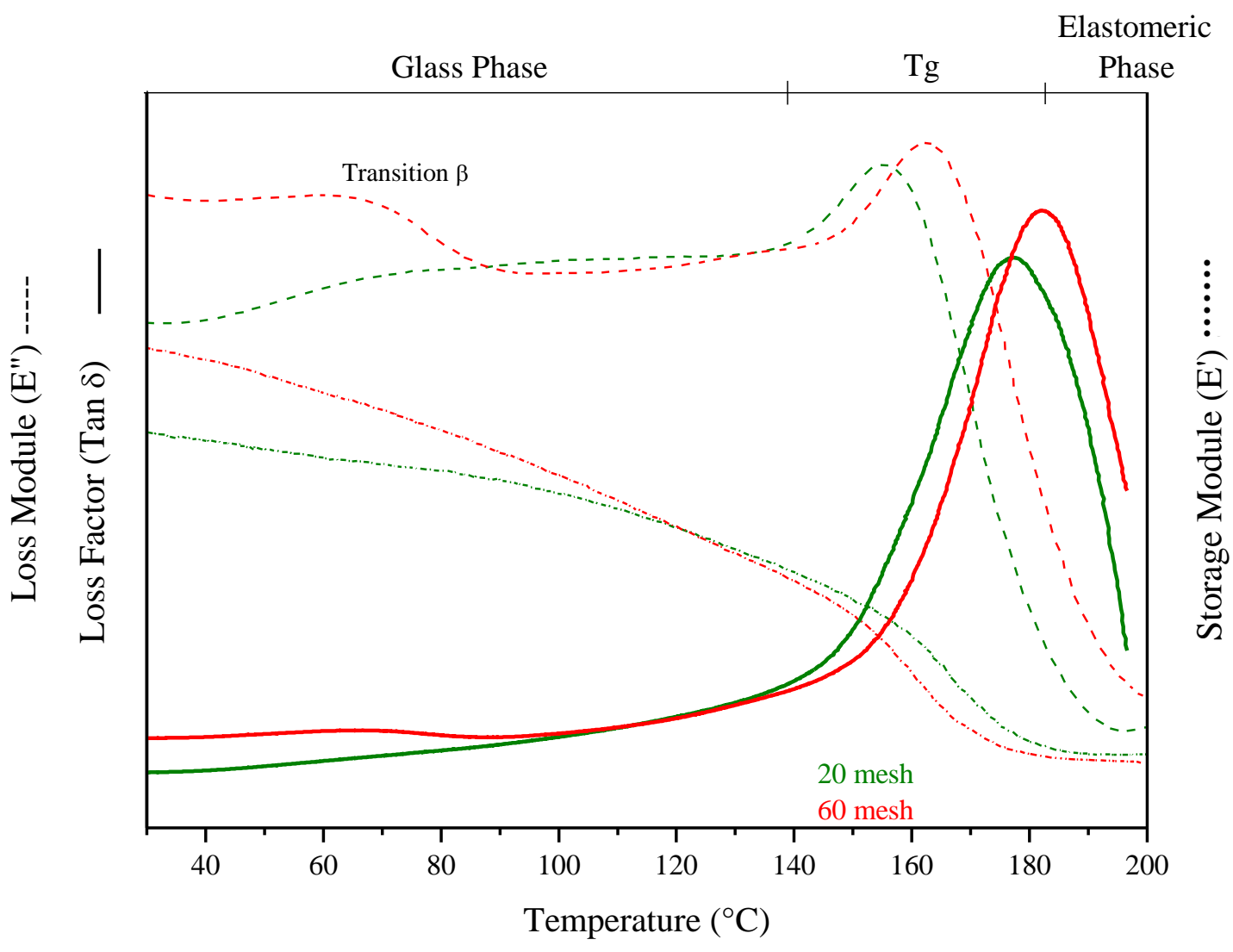

Source: Authors. 
Figure 5 shows the transitions from the heating of the cellulose acetate membranes, in which it is possible to identify a change, in this study called $\beta$, due to the relaxation of the side groups and movements of small segments of the polymeric chain containing at least four atoms of carbon (Feng \& Guo, 2016). This transition is more accentuated in the 60 mesh sample due to its higher percentage of acetyl groups when compared to the 20 mesh.

The glass transition temperature $(\mathrm{Tg})$ is the temperature at which the polymer chains begin to move on a large scale (Hall, 1989) related to the rotational movements of the amorphous phase (Lorandi et al., 2016), in the case of a second order transition. Several studies consider that Tg corresponds to the highest value of the loss factor (Tan $\delta$ ) (Akay, 1993; Rezaei, Yunus \& Ibrahim, 2009; Niedermann, Szebényi \& Toldy, 2015), others define it by the maximum value of the loss module (Murugan, Ramesh \& Padmanabhan, 2014; Costa, Paiva, Botelho \& Rezende, 2003), or due to the temperature at which there is a more marked change in the storage module (Lorandi et al., 2016).

Akay et al. (1993) report that the maximum point of the loss factor occurs at the end of the glass transition region, while the maximum point of the loss module occurs at its midpoint. Thus, due to divergences in the literature, in this study $\mathrm{Tg}$ will be considered not as a single temperature, but as an interval, as shown in figure 5 .

According to Neto (2015), the more crystalline the material, the lower the intensity of the loss factor (Tan $\delta$ ) and the greater the molecular mass of the polymer, the greater the elastomeric plateau due to the greater entanglement between the chains.

Thus, it can be verified that the 20 mesh membrane is more crystalline than the 60 mesh, a result consistent with the stress / deformation analysis, since the 20 mesh membrane has a higher Young's modulus, being more resistant to elastic deformation, because the crystalline regions have less mobility between the polymer chains. However, it is not possible to identify differences in the elastomeric plateaus of the membranes.

The higher the material loss module, the greater its capacity to dissipate stored energy and the more flexible it will be. So, the 60 mesh membrane is more flexible than the 20 mesh, a fact also shown in Table 3, in which the Young's modulus of the membranes is compared.

As the graph presented for Loss Module (E'), Storage Module (E') and Loss Factor (Tan $\delta$ ) does not present the values obtained for each quantity, these are described in table 4.

Table 4. Maximum values obtained for Loss Module (E”), Storage Module (E') and Loss Factor (Tan $\delta$ ) of the cellulose acetate membranes.

\begin{tabular}{ccccc}
\hline Membrane & $\begin{array}{c}\text { Transition } \\
\beta(\mathrm{MPa})\end{array}$ & $\begin{array}{c}\text { Loss Module } \\
\left(\mathrm{E}^{\prime}\right)(\mathrm{MPa})\end{array}$ & $\begin{array}{c}\text { Storage Module } \\
\left(\mathrm{E}^{\prime}\right)(\mathrm{MPa})\end{array}$ & $\begin{array}{c}\text { Loss Factor } \\
(\text { Tan } \delta)\end{array}$ \\
\hline 20 mesh & 72.96 & 89.17 & 1390.09 & 0.38 \\
60 mesh & 84.54 & 92.44 & 1744.34 & 0.41 \\
\hline
\end{tabular}

Source: Authors.

\section{Conclusion}

The results demonstrate that the guapuruvu fibers in the particle sizes of 20 and 60 mesh provided the synthesis of cellulose triacetates, as well as the synthesis of the membranes. The pulping and bleaching processes were efficient, allowing the removal of great part of the lignin from the raw material, improving the quality of the membranes, since in the cellulose acetate, the lignin acts as a contaminant, making the membranes fragile. The FTIR spectra showed specific changes in the bands of the samples, indicating that the acetylation processes occurred efficiently. DMA analysis showed differences in mechanical and crystallinity properties in the obtained membranes. Finally, all the analyzes showed that the granulometry 
directly interferes in the final material, thus, the homogenization of the particle size is essential for future reactions of modification of lignocellulosic materials. This condition, until now, has not been reported in the literature and suggests that granulometric separation can contribute for most chemical processes with lignocellulosic materials, and can assist in several areas, in particular, biorefineries. Thus, for future work, the X-ray diffraction analysis of cellulose acetate membranes obtained with guapuruvu is suggested, in order to verify the amorphous and crystalline phases and study the possible variables involved in this distribution, so that changes in chemical processes and fiber granulometry, allow to control the amount of chains in the amorphous and crystalline phases and thus allow to control the transparency and flexibility of the membranes, which would facilitate its application in several areas.

\section{Acknowledgement}

The authors would like to thank FAPESP (Processo:16/19896-2 Linha de fomento: Auxílio à Pesquisa - Regular), CNPq and "This study was financed in part by the Coordenação de Aperfeiçoamento de Pessoal de Nível Superior - Brasil (CAPES) - Finance Code 001". The authors would like to thank Conselho Nacional de Desenvolvimento Científico e Tecnológico (CNPq), Research Group of Lignocellulosic Materials - GPML and the Research Group of Biomass and Bioenergy - PPGBB.

\section{Conflicts of interest}

The authors declare that there are no conflicts of interest related to this article publication.

\section{References}

Abdel-Naby, A. S., \& Al-Ghamdi, A. A. (2014b). Chemical modification of cellulose acetate by N-(phenyl amino) maleimides: Characterization and properties. International Journal of Biological Macromolecules, 68, pp. 21-27. https://doi.org/10.1016/j.ijbiomac.2014.04.007.

Abdel-Naby, A. S., \& Al-Ghamdi, A. A. (2014a). Poly (vinyl chloride) blend with biodegradablee cellulose acetate in presence of N-(phenyl amino) maleimides. International Journal of Biological Macromolecules, 70, pp. 124-130. https://doi.org/10.1016/j.ijbiomac.2014.06.033.

Akay, M. (1993). Aspects of dynamic mechanical analysis in polymeric composites. Composites Science and Technology, 47(4), pp. 419-423. https://doi.org/10.1016/0266-3538(93)90010-E.

Alves, I. C. N., Gomide, J. L., Colodette, J. L., \& Silva, H. D. (2011). Caracterização tecnológica da madeira de Eucalyptus benthamii para produção de celulose kraft. Ciência Florestal, 21(1), pp. 167-174. https://doi.org/10.5902/198050982759.

ASTM (American Society for Testing and Materials) D871-96 (2004), Standard Test Method for Cellulose Acetate, ASTM International, West Conshohocken, PA, 2004.

ASTM (American Society for Testing and Materials) D1102-84 (2013), Standard Test Method for Ash in Wood, ASTM International, West Conshohocken, PA, 2013.

ASTM (American Society for Testing and Materials) D1103-60 (1977), Standard Test Method of test for alpha-cellulose in wood, ASTM International, Withdrawn, 1985.

ASTM (American Society for Testing and Materials) D1104-56 (1978), Standard Test Method of Test for Holocellulose in Wood, ASTM International, Withdrawn, 1985

ASTM (American Society for Testing and Materials) D1106-96 (2013), Standard Test Method for Acid-Insoluble Lignin in Wood, ASTM International, West Conshohocken, PA, 2013.

ASTM (American Society for Testing and Materials) D1110-84 (2013), Standard Test Methods for Water Solubility of Wood, ASTM International, West Conshohocken, PA, 2013.

Bilo, F., Pandini, S., Sartore, L., Depero, L. E., Gargiulo, G., Bonassi, A., Federici, S., \& Bontempi, E. (2018). A sustainable bioplastic obtained from rice straw. Journal of Cleaner Production, 200, pp. 357-368. https://doi.org/ 10.1016/j.jclepro.2018.07.252.

Biswas, A., Saha, B. C., Lawton, J. W., Shogren, R. L., \& Willett, J. L. (2006). Process for obtaining cellulose acetate from agricultural by-products. Carbohydrate Polymers, 64, pp. 134-137. https://doi.org/10.1016/j.carbpol.2005.11.002.

Botaro, V. R. (1992). Análise e caracterização por métodos físico-químicos da lignina de bagaço de cana-de-açúcar obtida pelo processo acetossolve, Dissertação de Mestrado, Universidade de São Paulo, São Carlos. 
Brum, S. S., Oliveira, L. C. A., Bianchi, M. L., Guerreiro, M. C., Oliveira, L. K., \& Carvalho, K. T. G. (2012). Síntese de acetato de celulose a partir da palha de feijão utilizando n-bromossuccinimida (nbs) como catalisador. Polímeros, 22(5), pp. 447-452. https://doi.org/10.1590/S0104-14282012005000061.

Callister, W. D. Jr. (2008). Ciência e engenharia de materiais: uma introdução. Rio de Janeiro: LTC, 707 p. ISBN 978-85-216-1595-8.

Candido, R. G., \& Gonçalves, A. R. (2016). Synthesis of cellulose acetate and carboxymethylcellulose from sugarcane straw. Carbohydrate Polymers, 152, pp. 679-686. https://doi.org/10.1016/j.carbpol.2016.07.071.

Canevarolo, S. V. Jr. (2013). Ciência dos polímeros: Um texto básico para tecnólogos e engenheiros. (3ª edição) : Artliber Editora.

Cao, L, Luo, G., Tsang, D. C. W., Chen, H., Zhang, S., \& Chen, J. (2018). A novel process for obtaining high quality cellulose acetate from green landscaping waste. Journal of Cleaner Production, 176, pp. 338-347. https://doi.org/10.1016/j.jclepro.2017.12.077.

Carvalho, C. J. R. (2005). Respostas de plantas de Schizolobium amazonicum [S. parahyba var. amazonicum] e Schizolobium parahyba [Schizolobium parahybum] à deficiência hídrica. Revista Árvore, 29(6), pp. 907-914. https://doi.org/10.1590/S0100-67622005000600009.

Carvalho, D. M., Silva, M. R., \& Colodette, J. L. (2014). Efeito da qualidade da madeira no desempenho da polpação kraft. Ciência Florestal, 24(3), pp. 677684. https://doi.org/10.1590/1980-509820142403015.

Cerqueira, D. A., Rodrigues Filho, G., Carvalho, R. A., \& Valente, A. J. M. (2010). Caracterização de acetato de celulose obtido a partir do bagaço de canade-açúcar por 1H-RMN. Polímeros, 20(2), pp. 85-91. https://doi.org/10.1590/S0104-14282010005000017.

Cerqueira, D. A., Rodrigues Filho, G., \& Meireles, C. S. (2007). Optimization of sugarcane bagasse cellulose acetylation. Carbohydrate Polymers, 69, pp. 579-582. https://doi.org/10.1016/j.carbpol.2007.01.010.

Costa, M. L., Paiva, J. M. F., Botelho, E. C., \& Rezende, M. C. (2003). Avaliação térmica e reológica do ciclo de cura do pré-impregnado de carbono/epóxi. Polímeros: Ciência e Tecnologia, 13(3), pp. 188-197. https://doi.org/10.1590/S0104-14282003000300009.

Cruz, A. C., Meireles, C. S., Ribeiro, S. D., Rodrigues Filho, G., Assunção, R. M. N., Cerqueira, D. A., Zeni, M., \& Poletto, P. (2011). Utilização do acetato de celulose produzido a partir da celulose extraída do caroço de manga como matriz para produção de sistemas microparticulados. Química Nova, 34(3), pp. 385389. https://doi.org/10.1590/S0100-40422011000300004.

Fan, G., Wang, M., Liao, C., Fang, T., Li, J., \& Zhou, R. (2013). Isolation of cellulose from rice straw and its conversion into cellulose acetate catalyzed by phosphotungstic acid. Carbohydrate Polymers, 94, pp. 71-76. https://doi.org/10.1016/j.carbpol.2013.01.073.

Feng, J., \& Guo, Z. (2016). Temperature-frequency-dependent mechanical properties model of epoxy resin and its composites. Composites Part B: Engineering, 85, pp. 161-169. https://doi.org/10.1016/j.compositesb.2015.09.040.

Freitas, R. R. M., Senna, A. M., \& Botaro, V. R. (2017). Influence of degree of substitution on thermal dynamic mechanical and physicochemical properties of cellulose acetate. Industrial Crops and Products, 109, pp. 452-458. https://doi.org/10.1016/j.indcrop.2017.08.062.

Gomide, J. L., Fantuzzi Neto, H., \& Regazzi, A. J. (2010). Análise de critérios de qualidade de madeira de eucalipto para produção de celulose kraft. Revista Árvore, 34(2), pp. 339-344. https://doi.org/10.1590/S0100-67622010000200017.

Gonçalves, J. L. M., Alvares, C. A., Behling, M., Alves, J. M., Pizzi, G. T., \& Angeli, A. (2014). Produtividade de plantações de eucalipto manejadas nos sistemas de alto fuste e talhadia, em função de fatores edafoclimáticos. Revista Scientia Forestalis (IPEF), 42(103), pp. 411-419.

Hall C. (1989). Polymer materials. (2 edição): Macmillan, p. 50.

Hwang, K.-R., Jeon, W., Youn Lee, S., Kim, M.-S., \& Park, Y.-K. (2020). Sustainable bioplastics: recent progress in the production of bio-building blocks for the bio-based next-generation polymer PEF. Chemical Engineering Journal, p. 390. https://doi.org/10.1016/j.cej.2020.124636.

Joaquim, A. P., Tonoli, G. H. D., Santos, S. F., \& Savastano Junior, H. (2009). Sisal organosolv pulp as reinforcement for cement based composites. Materials Research, 12(3), pp. 305-314. https://doi.org/10.1590/S1516-14392009000300010.

Loo, M. M. L., Hashim, R., \& Leh, C. P. (2012). Recycling of valueless paper dust to a low grade cellulose acetate: Effect of pretreatments on acetylation. BioResources, 7(1), pp. 1068-1083.

Lorandi, N. P., Cioffi, M. O. H., \& Ornaghi Junior, H. (2016). Análise dinâmico-mecânica de materiais compósitos poliméricos. Scientia cum Indústria, 4(13), pp. 48-60. https://doi.org/10.18226/23185279.v4iss1p48.

Luckachan G., E., \& Pillai, C. K. S. (2011). Biodegradable polymers - A review on recent trends and emerging perspectives. Journal of Polymers and the Environment. 19, pp. 637-676. https://doi.org/10.1007/s10924-011-0317-1.

Melo, R. R., Menezzi, C. H. S. D., Souza, M. R., \& Stangerlin, D. M. (2013). Avaliação das propriedades físicas, químicas, mecânicas e de superfície de lâminas de paricá. Floresta e Ambiente, 20(2), pp. 238-249. https://doi.org/10.4322/floram.2013.004.

Mendes, G., Faria, M., Carvalho, A., Gonçalves, M. C., \& Pinho, M. N. (2018). Structure of water in hybrid cellulose acetate-silica ultrafiltration membranes and permeation properties. Carbohydrate Polymers, 189, pp. 342-351. https://doi.org/10.1016/j.carbpol.2018.02.030.

Murugan, R., Ramesh, R., \& Padmanabhan, K. (2014). Investigation on static and dynamic mechanical properties of epoxy based woven fabric glass/carbon hybrid composite laminates. Procedia Engineering, 97, pp. 459-468. https://doi.org/10.1016/j.proeng.2014.12.270.

Narita, D. K., Nakashima, G. T., Róz, A. L., Pires, A. A. F., \& Yamaji, F. M. (2018). Uso do guapuruvu (Schizolobium Parahyba) para fins energéticos. Ciência Florestal, 28(2), pp. 758-764. https://doi.org/10.5902/1980509832089. 
Neto, S. C. (2015). DMA - O que é preciso saber antes de sua utilização (parte IV). Brazilian Journal of Thermal Analysis, 4, 48E-50E.

Niedermann, P., Szebényi, G., \& Toldy, A. (2015). Characterization of high glass transition temperature sugar-based epoxy resin composites with jute and carbon fibre reinforcement. Composites Science and Technology, 117, pp. 62-68. https://doi.org/10.1016/j.compscitech.2015.06.001.

Peredo, K., Reyes, H., Escobar, D., Veja-lara, J., Berg, A., \& Pereira, M. (2015). Acetylation of bleached Kraft pulp: Effect of xylan content on properties of acetylated compounds. Carbohydrate Polymers, 117, pp. 1014-1020. https://doi.org/10.1016/j.carbpol.2014.10.004.

Pinheiro, R. C, Tonello, K. C., Valente, R. O. A., Mingoti, R., \& Santos, I. P. (2011). Ocupação e caracterização hidrológica da microbacia do córrego Ipaneminha, Sorocaba-SP. Irriga, 16(3), pp. 234-245. https://doi.org/10.15809/irriga.2011v16n3p234.

Popescu, C. M., Larsson, P. T., Olaru, N., \& Vasile, C. (2012). Spectroscopic study of acetylated kraft pulp fibers. Carbohydrate Polymers, 88, pp. 530-536. https://doi.org/10.1016/j.carbpol.2011.12.046.

Protássio, T. P., Bufalino, L., Tonoli, G. H. D., Couto, A. M., Trugilho, P. F., \& Guimarães Júnior, M. (2011). Relação entre o poder calorífico superior e os componentes elementares e minerais da biomassa vegetal. Pesquisa Florestal Brasileira, 31(66), pp. 113-122. https://doi.org/10.4336/2011.pfb.31.66.113.

Ramakrishnan, N., Sharma, S., Gupta, A., \& Alashwal, B. Y. (2018). Keratin based bioplastic film from chicken feathers and its characterization. International Journal of Biological Macromolecules, 111, pp. 352-358. https://doi.org/10.1016/j.ijbiomac.2018.01.037.

Ren, J. L., Sun, R. C., Liu, C. F., Cao, Z. N., \& Luo, W. (2007). Acetylation of wheat straw hemicelluloses in ionic liquid using iodine as a catalyst. Carbohydrate Polymers, 70, pp. 406-414. https://doi.org/10.1016/j.carbpol.2007.04.022.

Rezaei, F., Yunus, R., \& Ibrahim, N. A. (2009). Effect of fiber length on thermomechanical properties of short carbon fiber reinforced polypropylene composites. Materials \& Design, 30(2), pp. 260-263. https://doi.org/10.1016/j.matdes.2008.05.005.

Rodrigues Filho, G., Monteiro, D. S., Meireles, C. S., Assunção, R. M. N., Cerqueira, D. A., Barud, H. S., Ribeiro, S. J. L., \& Messadeq, Y. (2008). Synthesis and characterization of cellulose acetate produced from recycled newspaper. Carbohydrate Polymers, 73 , pp. 74-82. https://doi.org/10.1016/j.carbpol.2007.11.010.

Santos, R., Mello Júnior, J. A., Caraschi, J. C., Ventorim, G., \& Pereira, F. A. (2016). Polpação kraft e kraft/aq da madeira pré-hidrolisada de híbrido de Eucalyptus Urophylla x Grandis. Ciência Florestal, 26(4), pp. 1281-1290. https://doi.org/10.5902/1980509825148.

Senna, A. M., Menezes, J., \& Botaro, V. R. (2013). Estudo da densidade de ligações cruzadas em géis superabsorventes obtidos do acetato de celulose. Polímeros, 23(1), pp. 59-64. https://doi.org/10.1590/S0104-14282012005000078.

Severo, E. T. D., Calonego, F. W., \& Sansígolo, C. A. (2006). Composição química da madeira de Eucalyptus citriodora em função das direcções estruturais. Silva Lusitana, 14(1), pp. 113-126.

Shaikh, H. M., Pandare, K. V., Nair, G., \& Varma, A. J. (2009). Utilization of sugarcane bagasse cellulose for producing cellulose acetates: Novel use of residual hemicellulose as plasticizer. Carbohydrate Polymers, 76, pp. 23-29. https://doi.org/10.1016/j.carbpol.2008.09.014.

Silva, J. P. (2018). Potencial de uso de fibras de Schizolobium parahyba (vell.) blake na preparação de compósitos de polipropileno. Dissertação de Mestrado, Universidade Federal de São Carlos, Sorocaba.

Sun, R., Fang, J. M., Tomkinson, J., \& Jones, G. L. (1999). Acetylation of wheat straw hemicelluloses in N,N-dimethylacetamide:LiCl solvent system. Industrial Crops and Products, 10, pp. 209-218. https://doi.org/10.1016/S0926-6690(99)00025-4.

TAPPI (Technical Association of Pulp and Paper Industry) Standard Method T204 cm-97 - Tappi Test Methods, 2007.

Trugilho, P. F., Goulart, S. L., Assis, C. O., Couto, F. B. S., Alves, I. C. N., Protásio, T. P., \& Napoli, A. (2015). Características de crescimento, composição química, física e estimativa de massa seca de madeira em clones e espécies de Eucalyptus jovens. Ciência Rural, 45(4), pp. 661-666. https://doi.org/10.1590/0103-8478cr20130625.

Vidaurre, G. B., Carneiro, A. C. O., Vital, B. R., Santos, R. C., \& Valle, M. L. A. (2012). Propriedades energéticas da madeira e do carvão de paricá (Schizolobium amazonicum). Revista Árvore, 36(2), pp. 365-371. https://doi.org/10.1590/S0100-67622012000200018.

Vivian, M. A., Segura, T. E. S., Bonfatti Júnior, E. A., Sarto, C., Schmidt, F., Silva Júnior, F. G., Gabov, K., \& Fardim, P. (2015). Qualidade das madeiras de Pinus taeda e Pinus sylvestris para a produção de polpa celulósica kraft. Scientia Forestalis, 43(105), pp. 183-191.

Walker, S., \& Rothman, R. (2020). Life cycle assessment of bio-based and fossil-based plastic: A review. Journal of a Cleaner Production, p. 261. https://doi.org/10.1016/j.jclepro.2020.121158.

Wang, B., \& Li, R. (2018). Inhibition of hornification of Eucalyptus kraft pulp by acetylation. IOP Conference Series: Earth and Environment Science, p. 170. https://doi.org/10.1088/1755-1315/170/5/052023.

Zhang, G., Huang, K., Jiang, X., Huang, D., \& Yang, Y. (2013). Acetylation of rice straw for thermoplastic applications. Carbohydrate Polymers, 96, pp. 218226. https://doi.org/10.1016/j.carbpol.2013.03.069. 